\title{
HOW TO MINIMIZE URBAN FLOODING: PERMISSIBLE ARCHITECTURE AND URBAN PLANNING
}

\author{
Maria Augusta Justi Pisani ${ }^{1}$ \\ Gilda Collet Bruna ${ }^{2}$
}

\begin{abstract}
The floods in urbanized areas damage systemically the Brazilian municipalities during the high raining periods. The economic lost that the nation face with this phenomenon are not yet measured, although through the impacts' extension it is possible to observe that they are affecting the South and Southeast regions during this decade. Disasters within the urban tissue are complex, as they turn the various types of risks in a mess, mixing the natural risks with the social ones and also with the technological and biological risks. If society occupies inadequate areas like the floodplains of the rivers and change the hydrological regime of the river basins, they pay a higher price, both with the public works to control these floods, and with the losses generated with floods and their aftermath. So, controlling a flood means intervene in several processes and involved elements, trying to minimize their effects. The recognition and monitoring of areas subject to risk are indispensable tools to for avoiding or reducing the undesired effects and the measures that assist the management of flooded areas are: maintenance, structural and non structural measures.

This article objective is to study the potentialities of the non structural measures to combat the accidents related to floods, through a local research. These measures can be adopted by the architects and urban planners and engineering professionals and collaborate in a systemic and efficient form to decrease these natural disasters damages and frequency.

The first methodological procedure used for this research was the survey of actions and public works implemented in European, Asian and American cities during the last decade and analyze the probability of adapting these works to the Brazilian reality. These research findings are important subsidies for the public policies and urban projects development so that they minimize the urban floods, thus helping the sustainable development.
\end{abstract}

Keywords: Urban Floods; Non Structural Measures; Fighting Floods.

\section{FLOODS IN BRAZILIAN CITIES}

Selecting the events related to floods the most significant in Brazil, Calheiros (2002, p.4-5) highlights that in the North the Amazon River and its riparian areas suffer constant flooding and the basin of the Rivers Madeira, Tapajós, Xingu, Negro and Tocantins and also the city of Rio Branco, due to the influence of the melting of the Andes. In the Northeast floods of the Rivers São Francisco, Jaguaribe, Parnaíba, de Contas and the Paraguaçu are the most recurrent, and, despite this region has few inhabitants than the Southeast already in 1985 the floods hit more than one million people.In the Midwest floods happen annually in Pantanal that is the ballast of the whole system of environment and water resources that produce flood in the cities of Goiás, fed by the Araguaia River. In the South

Mackenzie University. augustajp@gmail.com

2 Mackenzie University. gildacbruna@gmail.com 
region floods are consistently related to the Rivers Uruguai, do Peixe, tubarão, Paraná, Iguaçu, Taquari and Guaiba, and Santa Catarina State has been considered the most fragile state due to floods and landslides of large common in this decade. In the Southeast region, which concentrates the large economy and population of the country, the flooding Rivers Tietê, Paraná, Paraibuna and Doce, and the landslides on slopes, cause serious social and economic impacts in the metropolitan areas of São Paulo and Rio de Janeiro. Sometime whole towns were devastated by the joint action of floods, landslides and mudslides, as had happened in 1967 in Caraguatatuba in São Paulo, in 2001 in Goiás Velho, in 2008 in Blumenau in Santa Catarina, and in 2010 in São Luís do Paraitinga, São Paulo.

Every year in the rainy periods the episode repeats itself: the press gives great prominence to incidents and collects decisions of the local, state and federal governments; the population is sensitive and promotes actions of emergency aids, the subject is discussed throughout the country by technicians, victims, politicians and citizens. However, after few months the intense rains cease, accidents become rare and the matter is forgotten or ignored; nevertheless the practices of occupation of the river valleys continue: it seems there is ignorance or indifference of local governments, which ends up working as an incentive for the occupancy of undue areas of risks. According to the Civil National Defense Secretariat (Brazil, 2004, p.5), the natural disasters produced higher damages than those done by the wars, and so the efforts to recognize and face these threats should be considered like investments of long return period.

In order to implement actions and public works to reduce the urban flooding it is important to count on multidisciplinary studies including architecture, urban planning, hydraulic and civil engineering, meteorology, geology, geography, sociology, psychology and social communication, all of them aiming at the sustainable development that takes care of the social well-being and the environment protection.

This article is concerned with the analysis of the non-structural measures to combat the flood related accidents especially those that concern the role of architecture and urbanism.
The non-structural measures are those that have extensive character with actions that hit all the basin, of institutional nature, administrative or financially, adopted individually or by group, spontaneously or enforced by law, aimed at minimizing impacts and to adapt residents to live with the phenomenon. (São Paulo, 1984, s/p). The non-structural measures are those that have shown more efficiency in the various measures to minimize the problems caused by floods compared to structural measures, which are:

Non-structural measures are studied: retention in the soil; living with de development of building designs with appropriate typology; the transfer of buildings hit hard; elevation of existing structures; discipline in the use and occupation with planning and the management of the watersheds; municipal plan of risk; flood insurance; and development of urban policies adequate to the characteristics of the municipality.

\section{Retention in the soil}

One of the guidelines used by most planners and architects is the adoption of permable areas. These are built using the structures for retention and temporary storage of water as big pools and the individual reservoirs. These water retentions can be seized or released after the rains, when the volume of water in the bottom of the valley is lower.

The planning, dimensioning and installation of infiltration systems are widely used in Europe (mostly based in German Standarts ATVDVWK- A 138). These systems should be designed taking into account the characteristics systems of the rainwater catchment in which it is set. For the temporary rainwater retention in the underground and later infiltration there are very efficient products, such as the "block of infiltration" (figure 1), tunnels of drainage and ballast stone draining.

In order that this workd function, they must be designed according to those architectural and urban conditions, because the presence of water in some built-up places can damage the foundations and other buried structures. 

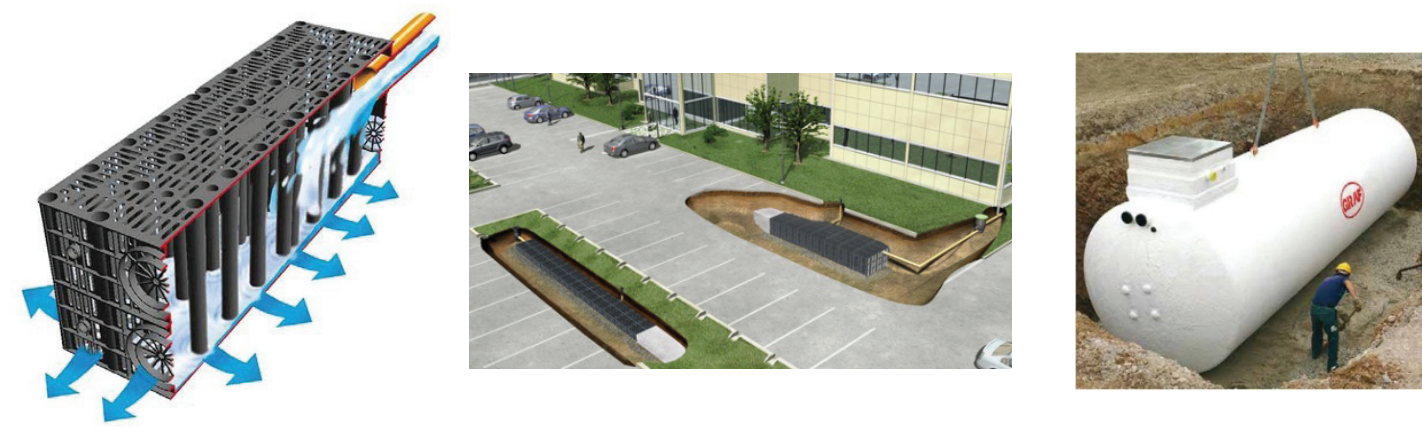

Figure 1 - Infiltration Block

Figure 2 - tunnel of infiltration

Figure 3 - storage tank for rainwater. Source: GRAF (2010)

\section{TYPOLIGY}

The elaboration of buildings' designs with appropriate typoligy so that they que be adaptable to floods is used in many countries. These can be done with various techniques like: temporary or permanent seal; construction of containment walls and dikes around the areas to protect; and compatible uses. Elevation of existing structures: many building typologies can live with the change in water level, for example, stilts, heavily used in Northen Brazil.
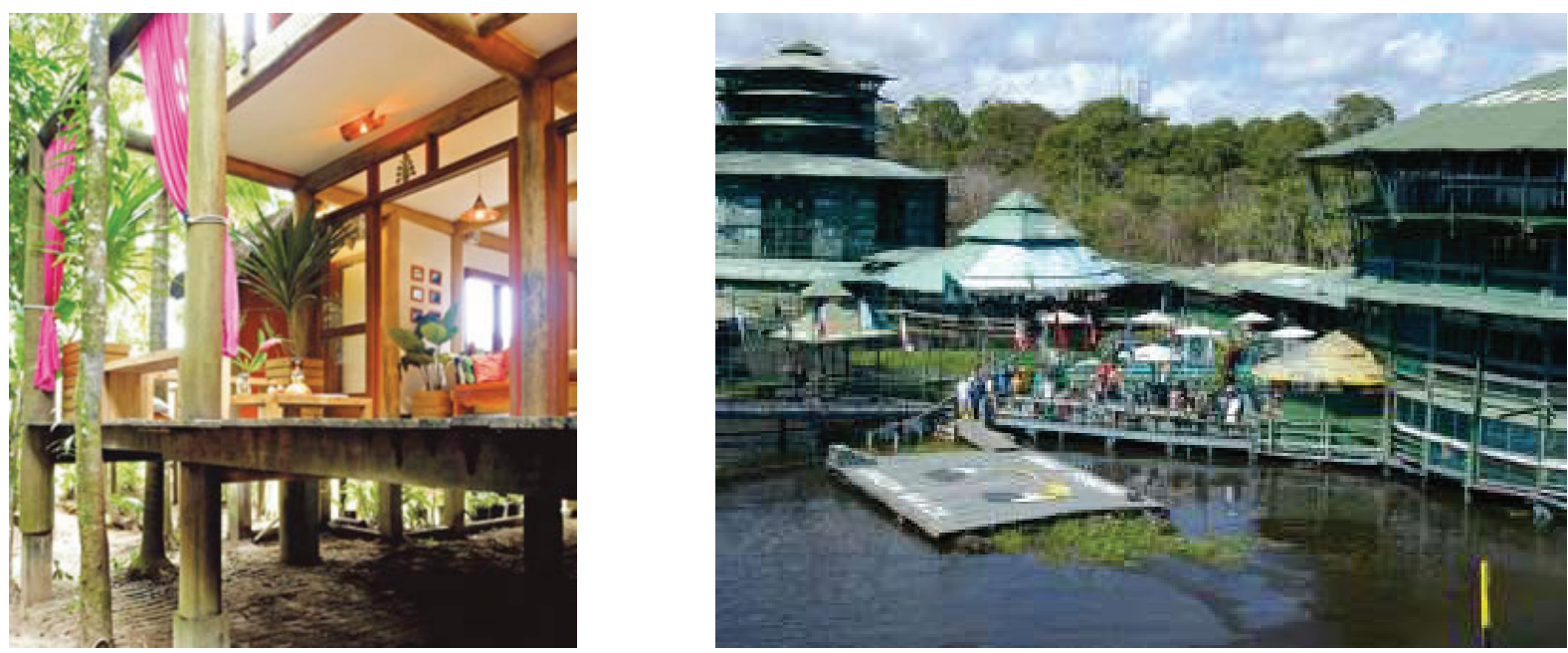

Figure 4 - contemporary house in stilts. Source: FARANO (2010) photo by Pedro Abude

Figure 5 - Ariaú Hotel in Amazonas. Source. Ariaú Gallery of Images

Available in http://www.ariau.tur.br/ accessed in 17/08/2010

\section{REMOVAL}

Since the 1980's the Brazilian public policies have opted for urbanizing areas of risk rather than remove them due to the huge number of residents who live in them. However in some cases removal of the buildings hardly hit toward safer places is inevitable, for example, when the occupation is set on floodable areas and the appropriated building typologies would be more costly than building a new housing design. In cases where the return of the population cannot happen on the areas previously flooded, as the events continue occurring and mainly where these populations commit the water resources, such as the case of the São Paulo Parque do Gato, a housing development built to move the inhabitants of the former Gato slum that occupied part of the bed of the Tamanduateí River in São Paulo. (figure 6) 


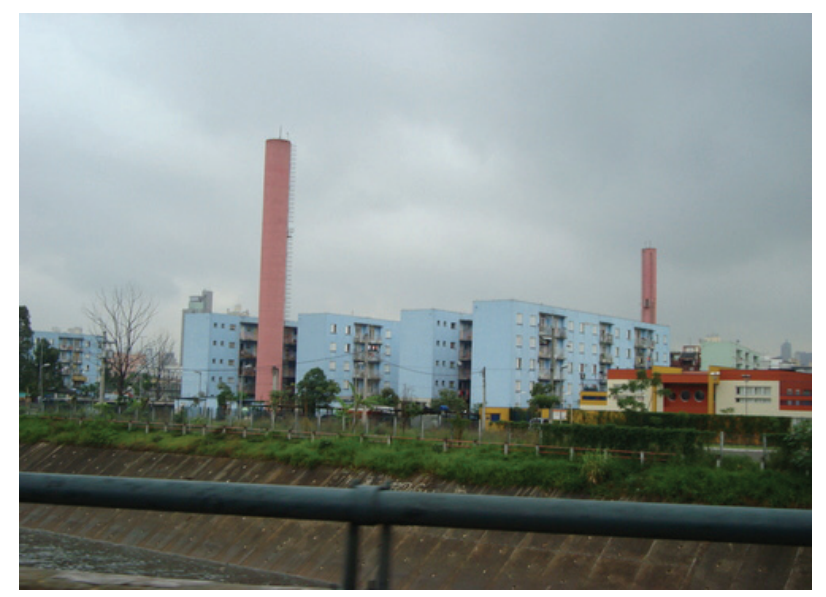

Figure 6 - São Paulo Parque do Gato. Source: Residential Parque do Gato. Site Panoramio

Available in: http://www.panoramio.com/photo/20558064. Accessed in 18/08/2010.

\section{LAND USE AND OCCUPATION DISCIPLINE:}

The planning and management of the watersheds are fundamental for the growth of urban areas does not exacerbate the problem. It is noteworthy that the Brazilian legislation for land use and occupation is demanding but not properly met, further actions are needed, such as: public awareness through ongoing programs of clarification and guidance from flooded areas with: zoning restrictions on land use and occupation; monitoring of areas subject to disasters, occupied or non occupied; continued education; encouragement of research.

By its turn the Master Plan of the Municipality as the main instrument for the control of the urban development, counting on the population participation in the decisions taken over their communities should be prioritized among the implementation of the government decisions, as well as this population should take care that this plan should be periodically revised enabling thus, systematically, the implementation of the improvements demanded by the community. As an instrument that direct the development policies, it deserver be periodically adequate to the city dynamic and, consequently, turned to the attendance of the population's wishes. That way each local in the municipality is valued with its peculiarities and each community there located that participates in the planning decisions contributes to the master plan act, as also receives the improvements the community has fought for.
The United Nations Office for the Reduction of Disasters (UNDRO- Office of the Disaster ReliefCo-Ordinator) in 1991 elaborated a methodological plan for the work ahead to natural hazards, based on two things: prevention and preparedness (UNDRO, 1991). The prevention is directly related with the measures that can be taken before the disasters, to avoid them or minimize their effects. The preparedness subsidizes the actions of emergence, before, during and after the disaster. To meet the goals of these two phases are recommended the following steps: hazard identification; mapping; risk analysis; prevention measures; structural and non-structural measures; planning for emergencies; public information; and training. One of the aids in risk management in areas prone to natural disasters, as shown in UNDRO (1991) is to act on the basis of the Municipal Plan for Risk Reduction (PMRR), this plan fostered by Ministry of Cities through the Urban Programs Secretariat.

\section{INTEGRATED MANAGEMENT OF WATER RESOURCES}

In the XXI century it is not common to address the water resources management in a fragmented way. This issue is being deep studied in the national and international researches and some authors like Barth (1996), Setti et al (2001), Campos and Studart (2001), Silva (2002) and Tucci (2005). They present the sustainable use of the water resources and the intensive use of nonstructural measures as the more reliable solutions to the contemporary cities. Thinking about sustainable development, which is a goal that is present in any Brazilian city Master Plan since the 1990's is to think in integrated management and in the multiple uses and actions that if on one hand saves potable water, which is a finishing resource, on the other hand it is important to prevent the excess of accumulated rainwater giving rise to floods in urbanized areas. The objectives of the integrated water resources management are: the protection of the water resources; the prevention of risks of accidents due to floods and landslides; and the compatibility of the regional plans, the municipal and environmental zoning with each other.

\section{FLOOD INSURANCE}

The insurance against floods was not adopted in a wide form in Brazil, like a non- struc- 
tural measure, sometimes for cultural reasons, sometimes due to this insurance cost that always has been high for the poor population that are the ones most hur by floods.

The insurance against floods allow the individual or juridical person a legal protection for economic losses arising from harmful events, after they have occurred. According to Andrade and Lacerda (2009), under the view point of insurers the premium set should cover the average costs of incidents, considering the accident in a given period of time, plus the costs of inspections, the management of policies, administrative expenses and management company taxes, profits and interest.

For those residents who pay their property insurance, they count on insurance windstorm, hurricane, cyclone, tornado, hail and smoke which may include damage resulting from the action of rainwater, building, and also falls from lighting, since it is concerned to the land on which stands the building that has done the insurance 1 . In the case of the flood occurred in 1999, in the Anhangabaú River valley, focusing the vehicles, the insurers come also to cover the damages, according to a technician of the Financing Business of PROCON-SP, even that the owner should pay for the franchise, and those who do not have insurance need to file a lawsuit against the government. In the case of other countries like the United States, insurers do not work with flood insurance.

\section{FLOOD WARNING SYSTEM}

In this item, the alert system of flooding is a tool that has proved a most effective in various cities around the world. In Brazilian cities it is used so there is time for decision making in the management of accidents
A Brazilian example is the São Paulo Flood Warning System (SAISP), which makes the São Paulo region hydrologic monitoring, involving the São Paulo metropolitan region, which is the Brazil's larger urbanized area and the most populous. The system is fed by the Department of Waters and Electric Energy of the State of São Paulo (DAEE) telemetric network and by the Meteorological Radar of São Paulo, which is propriety of the DAEE and was acquired through convention with the Foundation for Research Support of the State of São Paulo (FAPESP). The SAISP provides products such as maps of rainfall observed in the field of Radar New Bridge; and the readings of posts from the Network Telemetry Alto Tietê Cubatão, Registro and Piracicaba; and the maps with the forecasts of floods in the city of São Paulo.

The map with the floods prevision is a product that contains the hydrological forecast states, using an cause-effect algorithm based on the rain fall data observed and predicted by the radar. It is composed by two modules: minor drainage (floods caused by problems due to inadequate local drainage) and macro drainage (floods caused by overflowing streams and streams with low discharge capacity).

The forecast is done for the next three hours and is reevaluated each 20 minutes. The observations show that flooding due to insufficient micro drainage or lack of capacity of the sluice gate and culverts, depends little of the rain and more of the accumulated rain current. Thus the inference of state hydrological future is made by simply comparing the intensity of the rain provided with critical rain fall, coupled with the return period, which usually cause floods.
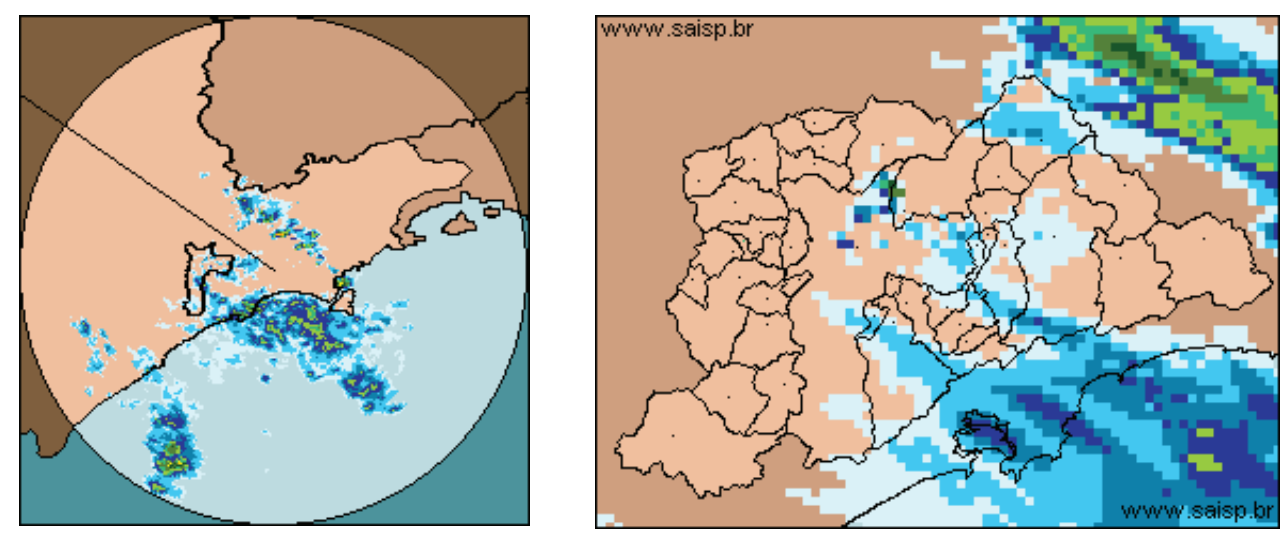

Figure 7 - SAISP products - Partial Reporto n Events of Rain - from 05/08/2010 02:20 (GMT) until 05/08/2010 10:00 (GNT). Source: SAISP (2010) 


\section{CONCLUSIONS}

The minimization of floods in urban areas requires integrated works and actions that satisfactory results are obtained. The systemic vision of all the water basin is needed and among the preventive measures, the non-structural ones have an extensive character and can be more aggressive against the accidents. The architect and urbanist technical and scientific knowledge in this area has increased the chances to minimize the urban floods, to the extent that they adopt in their projects, be urban, be of buildings, non-structural measures that together with the structural measures and with an efficient maintenance of these systems, will be able to eliminate the socioeconomic losses that resulted from these events.

\section{REFERENCES}

ANDRADE, E.S.M. e LACERDA, G.B.M. Mudanças Climáticas e Análise de Risco da Indústria do Petróleo no Litoral Brasileiro. Madri: Fundación MAPFRE, 2009. Disponível em: http:// www.mapfre.com/ccm/content/documentos/fundacion/cs-seguro/libros/mudancas-climaticas-eanalis. Acesso em 21/08/2010.

CALHEIROS, Lelio Bringel. Introdução. In: Brasil. Ministério da Integração Social. (MI). Secretaria Nacional de Defesa Civil. (SEDEC). Conferência geral sobre desastres: para prefeitos, dirigentes de instituições públicas e privadas e líderes comunitários. Brasília: MI, 2002. p. 3-6

CAMPOS, N.; STUDART, T. Gestão de águas: princípios e práticas. Porto Alegre: ABRH, 2001. 123p.

FARANO, Juliana. Elevada para preservar. Revista Casa e Construção, s/p. edição 48Dsiponível em:
http://festaviva.uol.com.br/ESCC/Edicoes/48/ imprime145721.asp acesso em 17/08/2010.

GRAF. Infiltración y drenaje: gestión de águas pluviales. Catalogo V28-2ES. Girona: GRAF, 2008

GRAF. Site empresarial. Disponível em: http:// www.grafiberica.com/grupo-graf/empresa.html acesso em 17/08/2010

SAISP - Sistema de Alerta a Inundações de São Paulo. RELATÓRIO PARCIAL DE EVENTO DE CHUVA - DE 05/08/2010 02:20(GMT) ATÉ 05/08/2010 10:00(GMT) em 05/agosto/2010. Disponível em: http://www.saisp.br/online/ Acesso em 16/08/2010.

SETTI, A. A.; LIMA, J. E. F. W.; CHAVES, A. G. M.; PEREIRA, I. C. Introdução ao gerenciamento de recursos hídricos. Brasília-DF, 2 ed., ANEEL, ANA, 2001, 235 p.

SILVA, R. T. Gestão hidrográfica de bacias densamente urbanizadas. Em FONSECA, R. B.; DAVANZO, A. M. Q. e NEGREIROS, R. M. C. Livro verde. Desafios para a gestão da Região Metropolitana de Campinas. Campinas, Unicamp, Instituto de Economia, 2002.

TUCCI, Carlos E.M. Curso de Gestão das inundaçôes urbanas. Porto Alegre: UNESCO Global Water Partneship South America, 2005.

UNDRO - UNITED NATIONS DISASTER RELIEF OFFICE. UNDRO's approach to disaster mitigation.UNDRO News, jan.-febr.1991. Geneva: Office of the United Nations Disasters Relief Coordinator, 1991 